\title{
Respiratory symptoms, atopy and bronchial hyperreactivity in professional firefighters
}

\author{
D. Miedinger*,\#, P.N. Chhajed*, D. Stolz*, C. Gysin*, A-B. Wanzenried*, \\ C. Schindler", C. Surber ${ }^{+}$, H.C. Bucher ${ }^{\#}$, M. Tamm* and J.D. Leuppi* ${ }^{\star *}$
}

ABSTRACT: The aim of the present study was to assess respiratory health in professional firefighters.

A total of 101 male professional firefighters from Basel, Switzerland, were included in the study. A control group consisting of 735 male subjects of the general population was composed of the Basel sample of the Swiss Study on Air Pollution and Lung Diseases in Adults. All subjects were administered a standardised questionnaire, spirometry, skin-prick tests and bronchial challenge testing to methacholine.

Respiratory symptoms at work were more frequent in firefighters compared with the control group, including burning eyes (21 versus $3 \%$ ), running nose (19 versus $2 \%$ ), itchy throat (26 versus $3 \%$ ), cough (28 versus $3 \%$ ), dyspnoea (7 versus $2 \%$ ) and headache (25 versus $3 \%$ ), respectively. Atopy was present in $\mathbf{5 1 \%}$ of firefighters compared with $32 \%$ in the control group. The odds ratio for hyperreactivity to methacholine was 2.24 (95\% confidence interval 1.12-4.48) for firefighters compared with the control group.

Firefighters reported more respiratory symptoms at work and suffered more often from atopy compared with the control group. Bronchial hyperreactivity was more pronounced in firefighters, but it was not related to acute exposure or duration of employment. It remains unclear whether these findings were present at recruitment or developed after joining the workforce.

KEYWORDS: Airway hyperresponsiveness, atopy, firefighter, respiratory symptoms

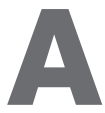
ccording to the Swiss Study on Air Pollution and Lung Diseases in Adults (SAPALDIA), $7 \%$ of the Swiss population have bronchial asthma and 19\% suffer from allergic rhinitis. Studies from this cohort have shown that air pollution leads to an increase in respiratory symptoms and a decline in lung function. Fire-fighting is a physically demanding and hazardous occupation [1, 2]. While at work, firefighters are at risk of exposure to various irritants or pollutants and hence wear selfcontained breathing apparatus (SCBA) during periods of visible smoke exposure [3].

After fire-fighting, an increased prevalence in respiratory symptoms [4], temporal decreases in lung function parameters (forced expiratory volume in one second (FEV1) and forced vital capacity (FVC) $[5,6]$ and an increase in airway hyperresponsiveness have been observed in members of municipal fire-fighting brigades in the USA $[7,8]$. A season of wildland fire-fighting has been shown to increase airway hyperresponsiveness [9]. Firefighters involved in rescue operations during the World Trade Center attack
(New York, NY, USA) in 2001 had a greater annual reduction in FEV1 and FVC [10] and showed persistent airway hyperresponsiveness, which was associated with the intensity of exposure at the disaster site [11-14].

Exposure to air pollutants (combustion products) can lead to increased sensitisation to airway allergens [11, 15-18]. No data are available regarding sensitisation to common airway allergens and allergies in firefighters, who are also at increased risk of exposure to air pollutants. During recent decades, the toxicity of smoke encountered at the scenes of fire has increased due to the presence of different synthetic products which have been introduced in various construction activities [1]. Although the availability and effectiveness of protective devices such as SCBA [1] has increased, SCBA is insufficiently used by firefighters due to its weight and inconvenience [19], especially when smoke is not visible and during phases of overhaul or work in the second line (drivers, pump manipulators), when important exposure to combustion products may persist.

\section{AFFILIATIONS}

${ }^{*}$ Clinic of Pneumology,

${ }^{\#}$ Basel Institute for Clinical

Epidemiology, and

+Hospital Pharmacy, University

Hospital, and

IInstitute for Social and Preventive

Medicine, University of Basel, Basel,

Switzerland.

CORRESPONDENCE

D. Miedinger

Dept of Internal Medicine

University Hospital

4031 Basel

Switzerland

Fax: 41612654587

E-mail: miedingerd@uhbs.ch

Received:

February 072007

Accepted after revision:

May 172007

STATEMENT OF INTEREST

A statement of interest for this study can be found at

www.erj.ersjournals.com/misc/

statements.shtml 
There is a lack of data regarding respiratory symptoms, lung function and airway hyperresponsiveness in full-time municipal firefighters in Europe in spite of the fact that, in most countries, firefighters undergo pre-employment screenings to rule out active diseases which might impair their working ability or worsen diseases, such as bronchial asthma, when using respiratory protection devices. In Switzerland, firefighters undergo a pre-employment medical fitness check prior to enrolment [20]. Therefore, it might be perceived that firefighters have a lower prevalence of respiratory symptoms, atopy, airway hyperresponsiveness and asthma. Consequently, a cross sectional study was undertaken to compare the prevalence of respiratory symptoms, atopy and airway hyperresponsiveness in full-time municipal firefighters in the city of Basel, Switzerland, with a control group of the general population from the same area. Some results have been previously presented [21].

\section{SUBJECTS AND METHODS}

All full-time municipal firefighters from the inner-city district of Basel (200,000 inhabitants) were included in the present study. Of the 107 firefighters, 102 (95\%) agreed to participate in the study. The study was approved by the local ethics committee and all subjects gave written informed consent. For purposes of analysis the only female firefighter was excluded. Workers were involved in all types of work, including responding to a call, and thus all were exposed to similar conditions at the site of an incident on a rotation basis. The questionnaire from the SAPALDIA study was administered [22]. In the SAPALDIA study, skin-prick tests (SPT) were performed with Phazet allergen-coated steel lancets (Pharmacia ${ }^{\circledR}$, Uppsala, Sweden), which were no longer available at the time of the present study. Instead, steel lancets from ALK Abelló (Hørsholm, Denmark) were purchased. Different aeroallergens (six grass mixture (Dactylis, Festuca, Lolium, Phleum, Poa, Avena), three trees mixture (birch, alder, hazel), Alternaria, Cladosporium, cat and dog epithelium and Dermatophagoides pteronyssinus and D. farinae) were used with histamine and saline/glycerol solution as the positive and negative control (ALK Abelló), respectively. Reading and interpretation of the SPTs, spirometry, measurement of exhaled carbon monoxide and methacholine challenge testing were performed as previously described elsewhere [22].

In the SAPALDIA study, a random sample of 1,491 subjects was selected from the population of Basel inner district. Of these, all the male (735) participants were included for comparison. The core questionnaire used in that study was identical to the one used in the study of the European Community Respiratory Health Survey (ECRHS). The SAPALDIA Basel study centre was a certified ECRHS centre [23]. These subjects also underwent SPT (Parietaria, Birch pollen, Timothy grass pollen, Alternaria, Cladosporium, D. pteronyssinus, cat and dog epithelium), spirometry, methacholine challenge test and exhaled carbon monoxide measurement. Definitions for airway symptoms were used as previously described [18, 22, 24-29]. To characterise responsiveness to methacholine expressed as a two-point doseresponse slope, reference equations depending on individual characteristics (i.e. sex, age and baseline lung function) were used as described by JAYET et al. [30]. Atopy was defined as a positive response to at least one of the allergens tested. Physician-diagnosed asthma was defined as an affirmative answer to the questions "Do you have asthma?" and "Has this been confirmed by a doctor?"

\section{Statistics}

Continuous variables are expressed as mean \pm SD and categorical variables are expressed as relative frequencies and percentages. Fisher's exact test was used for testing differences in the prevalence of respiratory symptoms, the provocative dose of methacholine causing a $15 \%$ fall in FEV1 and allergy between groups. The results of body measurements, ventilatory capacity tests and measurements of airway hyperresponsiveness to methacholine were analysed using unpaired t-tests. The differences in dose-response ratio (DRR) between the SAPALDIA general population and firefighters were assessed using Mann-Whitney U-tests. In order to compare DRR with methacholine between firefighters and SAPALDIA, responsiveness to methacholine $>90$ th percentile was calculated as an indicator variable for each subject as described by JAYET et al. [30]. Subsequent logistic regression was performed with the indicator as a dependent variable and potentially influencing factors (age, physician-diagnosed asthma, wheezing in the previous 12 months, atopy, FEV1, FVC and FEV1/FVC ratio for the firefighters versus SAPALDIA) as independent variables. Odds ratios with corresponding 95\% confidence intervals (CI) were calculated for all predictors. A p-value $<0.05$ was considered to indicate statistical significance. All tests were two-tailed.

\section{RESULTS}

The mean \pm SD age of firefighters was $41 \pm 11$ yrs compared with $40 \pm 12$ yrs in the SAPALDIA Basel sample $(p=0.853$ table 1). Firefighters have been appointed to the job for a mean of $16 \pm 10$ yrs. The number of current smokers was similar in the firefighter and SAPALDIA Basel groups, whereas the number of never-smokers was significantly higher in the firefighters (table 2). The mean amount of daily cigarette consumption was 5 cigarettes $\cdot$ day $^{-1}$ in firefighters compared with 7 cigarettes $\cdot$ day $^{-1}$ in the general population $(p=0.04)$.

General respiratory symptoms based on the SAPALDIA questionnaire and the incidence of physician-diagnosed asthma was similar in both groups (table 3 ). When specifically asked for respiratory symptoms encountered during work, burning eyes, running nose, throat itching, cough, dyspnoea and headache were significantly more prevalent in firefighters when compared with the SAPALDIA Basel sample (table 4)

Overall, 51 (51\%) firefighters were atopic compared with 215 $(32 \%)$ individuals of the SAPALDIA Basel population $(\mathrm{p}<0.001$; table 5$)$. Duration of employment did not account for the differences in prevalence of respiratory symptoms and atopy (table 6).

Mean FEV1 \% predicted values were $103 \pm 12$ and $100 \pm 19 \%$ for firefighters and the SAPALDIA Basel population, respectively $(\mathrm{p}=0.053)$. The FVC was $97 \pm 14$ and $91 \pm 13 \%$ pred $(\mathrm{p}<0.001)$ and the FEV1/FVC ratio was $0.77 \pm 0.07$ and $0.75 \pm 0.09$, respectively $(p=0.078)$. Methacholine testing was performed in $96(96 \%)$ firefighters and $558(76 \%)$ subjects from the SAPALDIA Basel population. Methacholine testing was not 


\begin{tabular}{|c|c|c|c|c|}
\hline \multirow[t]{2}{*}{ TABLE 1} & \multicolumn{4}{|c|}{$\begin{array}{l}\text { Comparison of lung function and exhaled carbon } \\
\text { monoxide (CO) measurement in firefighters } \\
\text { compared with the SAPALDIA Basel sample }\end{array}$} \\
\hline & & Firefighters & SAPALDIA & p-value \\
\hline \multicolumn{2}{|l|}{ Subjects $\mathbf{n}$} & 101 & 735 & \\
\hline \multicolumn{2}{|c|}{ Age at examination yrs } & $41(23-64)$ & $40(18-62)$ & 0.853 \\
\hline \multicolumn{2}{|c|}{ Height $\mathrm{cm}$} & $178 \pm 6$ & $176 \pm 7$ & 0.026 \\
\hline \multicolumn{2}{|l|}{ Weight kg } & $83 \pm 12$ & $77 \pm 11$ & $<0.001$ \\
\hline \multicolumn{2}{|l|}{$B M I \mathbf{k g} \cdot \mathrm{m}^{-2}$} & $26.2 \pm 3.4$ & $24.7 \pm 3.5$ & $<0.001$ \\
\hline \multicolumn{2}{|l|}{ FEV $1 \%$ pred } & $103 \pm 12$ & $100 \pm 19$ & 0.053 \\
\hline \multicolumn{2}{|l|}{ FVC $\%$ pred } & $97 \pm 14$ & $91 \pm 13$ & $<0.001$ \\
\hline \multicolumn{2}{|c|}{$\mathrm{FEV}_{1} / \mathrm{FVC}$ ratio } & $0.77 \pm 0.07$ & $0.75 \pm 0.09$ & 0.078 \\
\hline \multicolumn{2}{|c|}{ Exhaled CO ppm } & $4 \pm 7$ & $15 \pm 16$ & $<0.001$ \\
\hline \multicolumn{2}{|c|}{ Subjects with co } & \multicolumn{3}{|c|}{$>10 \mathrm{ppm} \%$} \\
\hline \multicolumn{5}{|c|}{$\begin{array}{l}\text { Data are presented as mean (range) or mean } \pm \mathrm{SD} \text {, unless otherwise stated. } \\
\text { SAPALDIA: Swiss Study on Air Pollution and Lung Diseases in Adults; BMI: } \\
\text { body mass index; FEV1: forced expiratory volume in one second; \% pred: \% } \\
\text { predicted; FVC: forced vital capacity. }\end{array}$} \\
\hline
\end{tabular}

performed in four firefighters because they missed the scheduled appointment. One subject did not undergo methacholine challenge as he had a FEV1/FVC ratio of 0.59 , which increased $>15 \%$ after inhaling a short-acting bronchodilator. Fifteen $(16 \%)$ firefighters had a positive methacholine challenge test based on a fall in FEV1 $\geqslant 20 \%$ compared with $52(9 \%)$ from the SAPALDIA Basel population $(\mathrm{p}=0.06)$. The mean reactivity to methacholine, expressed as the continuous doseresponse rate \pm geometric mean, was $4.29 \pm 15.68$ and $5.44 \pm$ $39.30 \%$ decrease $\cdot \mu \mathrm{mol}^{-1}$ for firefighters and the SAPALDIA Basel population, respectively $(\mathrm{p}<0.001)$.

The odds ratio $(95 \% \mathrm{CI})$ to have responsiveness to methacholine $>90$ th percentile compared with the male SAPALDIA Basel population was 2.24 (1.12-4.48). In logistic regression analysis, the following factors influencing greater

\begin{tabular}{|c|c|c|c|}
\hline \multirow[t]{2}{*}{ TABLE 2} & \multicolumn{3}{|c|}{$\begin{array}{l}\text { Smoking status and second-hand smoke (SHS) } \\
\text { exposure in firefighters compared with the } \\
\text { control group }\end{array}$} \\
\hline & Firefighters & SAPALDIA & $p$-value \\
\hline Subjects $n$ & 101 & 735 & \\
\hline Current smoker & $32(32)$ & $294(40)$ & 0.128 \\
\hline Cigarettes day ${ }^{-1}$ & $5 \pm 11$ & $7 \pm 12$ & 0.044 \\
\hline Never-smoker & $44(44)$ & $241(33)$ & 0.034 \\
\hline $\begin{array}{l}\text { SHS in never- } \\
\text { smokers }\end{array}$ & $25(57)$ & $67(28)$ & $<0.001$ \\
\hline Former smoker & $23(23)$ & $197(27)$ & 0.470 \\
\hline $\begin{array}{l}\text { SHS in former } \\
\text { smokers }\end{array}$ & $8(35)$ & $50(25)$ & 0.327 \\
\hline
\end{tabular}

Data are presented as $n(\%)$ or mean $\pm \mathrm{SD}$, unless otherwise stated. SAPALDIA: Swiss Study on Air Pollution and Lung Diseases in Adults.

\begin{tabular}{lccc} 
TABLE 3 & $\begin{array}{c}\text { Respiratory symptoms in firefighters and the } \\
\text { control group }\end{array}$ \\
& Firefighters & SAPALDIA & p-value \\
\hline & 101 & 735 & \\
Subjects n & $15(15)$ & $141(19)$ & 0.342 \\
Wheezing & $12(12)$ & $72(10)$ & 0.483 \\
Wheezing with dyspnoea & $10(10)$ & $91(12)$ & 0.625 \\
Wheezing without cold & $13(13)$ & $100(14)$ & 1.000 \\
Nocturnal chest tightness & $4(4)$ & $48(7)$ & 0.386 \\
Rest dyspnoea & $12(12)$ & $139(19)$ & 0.098 \\
Exercise dyspnoea & $19(19)$ & $194(26)$ & 0.114 \\
Nocturnal cough & $5(5)$ & $46(6)$ & 0.824 \\
Nocturnal dyspnoea & $7(7)$ & $54(7)$ & 1.000 \\
Chronic cough & $4(4)$ & $69(9)$ & 0.088 \\
Chronic phlegm & $18(18)$ & $133(18)$ & 1.000 \\
Bronchitis & $8(8)$ & $74(10)$ & 0.595 \\
Chronic bronchitis & $6(6)$ & $60(8)$ & 0.556 \\
Physician-diagnosed & & & \\
$\quad$ asthma & & & \\
\hline
\end{tabular}

Data are presented as $n(\%)$, unless otherwise stated. SAPALDIA: Swiss Study on Air Pollution and Lung Diseases in Adults.

methacholine responsiveness were identified: 1) being a firefighter (2.39 (1.17-4.89); $\mathrm{p}<0.05) ; 2) \mathrm{FEV} 1 / \mathrm{FVC}$ ratio $<0.7$ (2.70 (1.69-4.35); p<0.01); 3) history of wheezing in the previous 12 months (2.17 (1.2-3.94); $\mathrm{p}<0.01)$; and 4) doctordiagnosed asthma (3.46 (1.63-7.33); $\mathrm{p}<0.01)$.

\section{DISCUSSION}

A high incidence of respiratory symptoms has been reported in firefighters [4, 5, 31]. In Croatian firefighters, MuSTAJBEGOVIC et al. [4] have reported a prevalence of chronic cough, chronic phlegm and chronic bronchitis in $>20 \%$ of subjects. These symptoms were less frequent in the present study population; however, cough was regularly encountered at work in $28 \%$ of firefighters (tables 3 and 4). The increased prevalence in the Croatian firefighters might be attributed to the higher

TABLE 4 Symptoms regularly encountered during work in firefighters and the control group

\begin{tabular}{lccc} 
Symptom & Firefighters & SAPALDIA & p-value \\
\hline Health disturbance & $9(9)$ & $63(9)$ & 0.851 \\
Burning eyes & $21(21)$ & $20(3)$ & $<0.001$ \\
Running nose & $19(19)$ & $17(2)$ & $<0.001$ \\
Throat itching & $26(26)$ & $21(3)$ & $<0.001$ \\
Cough & $28(28)$ & $20(3)$ & $<0.001$ \\
Dyspnoea & $7(7)$ & $13(2)$ & $<0.006$ \\
Wheezing & $2(2)$ & $9(1)$ & 0.632 \\
Fever & $1(1)$ & $2(<1)$ & 0.321 \\
Headache & $25(25)$ & $22(3)$ & $<0.001$ \\
Abdominal pain & $2(2)$ & $7(<1)$ & 0.298 \\
\hline
\end{tabular}

Data are presented as $n(\%)$, unless otherwise stated. SAPALDIA: Swiss Study on Air Pollution and Lung Diseases in Adults. 


\begin{tabular}{|c|c|c|c|}
\hline TABLE 5 Sensitisation a & d atopy & & \\
\hline Allergen & Firefighter & SAPALDIA & p-value \\
\hline Six-grass mixture & 25/101 (25) & & \\
\hline Timothy & & 132/699 (19) & \\
\hline Paretaria & & $5 / 693(1)$ & \\
\hline Three-tree mixture & 26/101 (26) & & \\
\hline Birch & & 86/699 (12) & \\
\hline Alternaria & 13/101 (13) & $9 / 679(1)$ & $<0.001$ \\
\hline Cladosporium & $7 / 100(7)$ & $1 / 673(1)$ & $<0.001$ \\
\hline Cat dander & 13/101 (13) & 28/669 (4) & $<0.001$ \\
\hline Dog dander & $14 / 101(14)$ & 23/699 (3) & $<0.001$ \\
\hline $\begin{array}{l}\text { Dermatophagoides pteronyssi- } \\
\text { nus }\end{array}$ & 28/101 (28) & $83 / 680(12)$ & $<0.001$ \\
\hline Dermatophagoides farinae & $31 / 101(31)$ & & \\
\hline \multicolumn{4}{|l|}{ Atopy } \\
\hline Same allergens ${ }^{\#}$ & $36 / 100(36)$ & $112 / 652(17)$ & $<0.001$ \\
\hline Wider definition & $51 / 100(51)$ & 215/663 (32) & $<0.001$ \\
\hline \multicolumn{4}{|c|}{$\begin{array}{l}\text { Data are presented as number of patients positive to allergen/number of } \\
\text { patients tested from group (\%). SAPALDIA: Swiss Study on Air Pollution and } \\
\text { Lung Diseases in Adults. }{ }^{\#} \text { : at least one skin-prick test positive to the following } \\
\text { antigens: Alternaria, Cladosporium, D. pteronyssinus, cat and dog dander; " : at } \\
\text { least one skin-prick test positive to one of the tested antigens. }\end{array}$} \\
\hline
\end{tabular}

prevalence of current smokers (53\%) compared with the Basel firefighters (32\%). An increase in upper and lower airway symptoms was reported in New York firefighters engaged in rescue operations during the World Trade Center attack in 2001 [14]. These firefighters had a low prevalence of cough $(2 \%)$ prior to responding to this incident, which might be related to the low prevalence of smoking $(3 \%)$ in the study population [14]. Respiratory symptoms were similar in the Basel firefighters when compared with the SAPALDIA Basel population (table 3 ). However, several respiratory symptoms regularly encountered during work were significantly more often reported in the Basel firefighters (table 4). Therefore, the general respiratory symptoms questionnaire used in epidemiological studies might be inadequate to assess respiratory symptoms of firefighters.

In the current study, firefighters had a significantly higher rate of atopy compared with the SAPALDIA Basel population (table 5). This increased rate of atopy in firefighters might be due to the exposure to pollutants encountered at the fire station or scenes of incidents and/or to motor vehicle exhaust fumes, as the Basel fire station is centrally located in a busy street. Firefighters are known to be at risk of exposure to diesel emissions and combustion products [32]. SCBA, which are recommended to be routinely used at scenes of incidents, are heavy, increase energy cost, lower work performance and impair postural and functional balance [33, 34]. Consequently, SCBA may not be used by firefighters, especially if there are no visible flames or smoke at the scene [19]. The appropriate equipment is often not used during the overhaul and clean-up phase after visible flames are extinguished despite the possible high concentration of combustion products even during this phase $[19,35]$. Air pollution has been shown to increase and

\begin{tabular}{|c|c|c|c|}
\hline \multirow[t]{3}{*}{ TABLE 6} & \multicolumn{3}{|c|}{$\begin{array}{l}\text { Wheezing, respiratory symptoms at the } \\
\text { workplace and atopy according to duration of } \\
\text { work as a firefighter }\end{array}$} \\
\hline & & \multicolumn{2}{|c|}{ Duration of work yrs } \\
\hline & & $\leqslant 10$ & $>10$ \\
\hline \multicolumn{2}{|l|}{ Subjects $n$} & 38 & 63 \\
\hline \multicolumn{2}{|c|}{ Wheezing in previous 12 months } & $6(16)$ & $9(14)$ \\
\hline \multicolumn{2}{|c|}{ Respiratory symptoms at the workplace } & $14(37)$ & $20(32)$ \\
\hline \multicolumn{2}{|l|}{ Atopy } & $21(55)$ & $29(46)$ \\
\hline
\end{tabular}

exacerbate respiratory symptoms or reduce the dose of allergen needed to provoke an allergic response in atopic subjects [36-38]. It has been hypothesised that air pollutants may promote airway sensitisation by altering the allergenic content of airborne particles that contain the different allergens $[36,39-43]$. Air pollution may damage the airway mucosa and affect the mucociliary clearance, easing the penetration and access of inhaled allergens to the cells of the immune system [36, 42, 44]. Pollen grains or allergen-bearing particles may interact with nitrogen dioxide and carbon particles, leading to an increased allergenicity [15-17, 45]. In an experimental human study, challenge with diesel exhaust particles and ragweed induced markedly higher ragweed-specific immunoglobulin E when compared with a challenge with ragweed alone [46]. An increased sensitisation to outdoor allergens has been shown in subjects living in streets with a high volume of traffic [18, 36, 47-49]. In comparison with the SAPALDIA study, the present study tested for more allergens: three tree mixture compared with birch pollen alone, and six grass mixture compared with timothy grass pollen. This may, at least partially, explain the higher rate of atopy in the population of firefighters when the definition of atopy as having at least one positive SPT to an allergen was used. However, when the analysis was limited only to the allergens that were tested in both groups the difference still exists. The highest rates of atopy (defined as at least one positive SPT to one of the allergens tested) were seen in firefighters aged 40-50 yrs (data not shown). It can be argued that younger firefighters have had less exposure to pollutants due to the shorter duration of service, whereas in firefighters with a longer duration of service there might be a selection of healthy workers and, therefore, workers with atopy and respiratory disease might change their profession. In addition, it has been shown that atopy prevalence decreases with age $[29,50]$ and that smoking is negatively related to atopy [29]. In the present population of firefighters, the smoking prevalence was lower than in the SAPALDIA Basel male population and, therefore, an atopy rate below the SAPALDIA Basel population should be expected. As SPTs are not routinely performed during the medical exam at conscription, it is unknown whether atopic subjects were selected for this profession. If this were the case, it seems that atopy does not influence the performance of the subject in the fitness test every firefighter candidate has to pass prior to employment. It seems that atopy alone only marginally 
limits performance in physical activity. KATELARIs et al. [51] have shown a high prevalence of atopy to at least one aeroallergen in athletes taking part in the 2000 Olympic Summer Games (Sydney, Australia). SPTs are not included in the pre-employment and routine medical examination of firefighters and, therefore, the exact impact of fire-fighting on the atopy status cannot be determined in the current study. Thus, SPTs could be included in the routine medical examination of firefighters.

In the current study, firefighters had a significantly higher vital capacity compared with the SAPALDIA Basel population (table 1). This might be due to the selection of healthy workers for this profession. A similar effect in professional divers has been attributed to the natural selection for diving, rather than a training effect [52]. Spirometry is routinely included in the preemployment medical assessment of potential fire-fighting recruits in Switzerland and individuals with impairment of lung function are declared unfit for service [20]. Asthmatic subjects are also refused enrolment in the fire-fighting brigade [20]. Airway challenge tests are not routinely performed in firefighters by the examining physician and are, instead, reserved for specific subjects [20]. A response to methacholine based on a fall in FEV1 $\geqslant 20 \%$ was similar in firefighters as well as the SAPALDIA Basel population. However, the doseresponse ratio to methacholine is argued to be a better predictor of bronchial hyperreactivity, particularly for epidemiological studies as it avoids censoring [53]. Furthermore, the response to methacholine based on a fall in FEV $1 \geqslant 20 \%$ varies depending on the maximum dose administered. In the current study, airway hyperresponsiveness based on the doseresponse ratio [53] to methacholine was significantly lower in firefighters compared with the SAPALDIA Basel population. As different factors may influence the value of the doseresponse ratio, JAYET et al. [30] calculated reference equations for relevant percentiles of the methacholine two-point doseresponse slope taking into account individual characteristics, such as sex, age and pre-test airway calibre. JAYET et al. [30] suggested the 90th percentile as a "cut-off" level for identifying asthmatics in a sample of subjects with self-reported physician-diagnosed asthma, yielding a sensitivity of $51 \%$. By using percentile equations, which take into account pre-test lung volume, the proportion of subjects with methacholine reactivity $>90$ th percentile is higher in firefighters than in the male SAPALDIA population ( 26 versus $13 \%$; $p=0.001$ ). The risk of having reactivity to methacholine $>90$ th percentile is double for firefighters compared with the male SAPALDIA population (odds ratio (95\% CI) 2.24 (1.12-4.48)). Self-reported physician-diagnosed asthma, wheezing in the previous 12 months and an FEV1/FVC ratio $<0.7$ were factors contributing to a reactivity to methacholine of $>90$ th percentile. A positive association between the degree of bronchial hyperresponsiveness and the level of FEV1 have been described previously [54], whereas wheezing in the previous 12 months is a cardinal symptom of asthma and is often used in epidemiological studies to define asthma in patients with a positive bronchial challenge test [55-57].

Unlike studies performed previously, this hyperreactivity was not related to an acute exposure to combustion products or a polluted environment since the present study was performed in a cross-sectional manner and individuals who had responded to an incident and were exposed to combustion products within the previous $24 \mathrm{~h}$ were rescheduled $[8,9,14$, 58]. Due to the pre-employment screening, the prevalence of asthma might be expected to be lower in firefighters compared with the general population. However, in the present study, current physician-diagnosed asthma numbers were similar in firefighters and the SAPALDIA Basel population. Of the six firefighters with current physician-diagnosed asthma, only two had a record with a confirmatory diagnosis of asthma by the board physician. Therefore, there is a possibility of underreporting symptoms during medical screening of firefighters. Potential under-reporting of symptoms and the current diagnosis of asthma have been reported in USA Air Force recruits [59]. The findings of the present study underline the value of performing objective tests prior to enrolment and also during routine medical examination of firefighters.

Working under respiratory protection with a SCBA or diving with a self-containing underwater breathing apparatus will lead to an increase in workload and, therefore, minute ventilation. When the bottle is filled, air is compressed and de-humidified to avoid corrosion of the metal parts of the breathing apparatus. When the air is released and decompressed during the use of the apparatus, it cools down (Boyle's law). When airway inflammation is present, the dry cold air could be a trigger for acute bronchoconstriction [60]. Indirect bronchial challenge tests, such as mannitol powder, adenosine 5'-monophosphate, hypertonic saline or exercise eucapnic voluntary hyperpnoea act via osmotic stimuli on inflammatory cells, which then release mediators such as histamine, leukotrienes and prostaglandins which act on smooth muscle cells [61]. As an acute impairment of lung function can influence work performance and therefore put the subject and co-workers in danger, it is suggested that individuals with a positive indirect challenge test should be declared unfit to work under respiratory protection and should be treated until airway inflammation has resolved. The status fit-for-duty should not be restored until these subjects have a negative indirect challenge test.

According to the study by SISTEK et al. [26], wheezing was the most sensitive single symptom of current active asthma. Based on the present findings, firefighters either develop asthma as a consequence of their job or the initial screening using a questionnaire and spirometry is insufficient.

Further studies are needed to determine the impact of professional fire-fighting on sensitisation to aeroallergens and bronchial hyperreactivity. To answer this question, SPTs and bronchial challenge tests should be performed at conscription and at regular intervals while active in the workforce. Exposure to airway irritants should be estimated by recording work duties (e.g. number of operations with exposure to airway irritants, type of work performed at the site and type of respiratory protection worn), by using personal air and dust sampling devices $[19,35]$ or by measuring biological indicators of exposure [62]. Furthermore, studies assessing the impact of atopy and bronchial hyperreactivity on work performance and medical leave are needed.

In summary, firefighters experience more respiratory symptoms at work compared with the general population and these 
symptoms have to be specifically asked about. Firefighters seem to have more atopy when compared with the general population, which might be related to the greater exposure to a polluted environment. Firefighters also have more bronchial hyperreactivity, which is not related to an acute exposure during a fire-fighting incident. It remains unclear whether these findings were present at recruitment or developed after joining the workforce.

\section{REFERENCES}

1 Guidotti TL, Clough VM. Occupational health concerns of firefighting. Annu Rev Public Health 1992; 13: 151-171.

2 Guidotti TL. Human factors in firefighting: ergonomic-, cardiopulmonary-, and psychogenic stress-related issues. Int Arch Occup Environ Health 1992; 64: 1-12.

3 Brandt-Rauf PW, Fallon LF Jr, Tarantini T, Idema C, Andrews L. Health hazards of fire fighters: exposure assessment. Br J Ind Med 1988; 45: 606-612.

4 Mustajbegovic J, Zuskin E, Schachter EN, et al. Respiratory function in active firefighters. Am J Ind Med 2001; 40: 55-62.

5 Large AA, Owens GR, Hoffman LA. The short-term effects of smoke exposure on the pulmonary function of firefighters. Chest 1990; 97: 806-809.

6 Musk AW, Smith TJ, Peters JM, McLaughlin E. Pulmonary function in firefighters: acute changes in ventilatory capacity and their correlates. Br J Ind Med 1979; 36: 29-34.

7 Sheppard D, Distefano S, Morse L, Becker C. Acute effects of routine firefighting on lung function. Am J Ind Med 1986; 9: 333-340.

8 Sherman CB, Barnhart S, Miller MF, et al. Firefighting acutely increases airway responsiveness. Am Rev Respir Dis 1989; 140: 185-190.

9 Liu D, Tager IB, Balmes JR, Harrison RJ. The effect of smoke inhalation on lung function and airway responsiveness in wildland fire fighters. Am Rev Respir Dis 1992; 146: 1469-1473.

10 Feldman DM, Baron SL, Bernard BP, et al. Symptoms, respirator use, and pulmonary function changes among New York City firefighters responding to the World Trade Center disaster. Chest 2004; 125: 1256-1264.

11 Banauch GI, Alleyne D, Sanchez R, et al. Persistent hyperreactivity and reactive airway dysfunction in firefighters at the World Trade Center. Am J Respir Crit Care Med 2003; 168: 54-62.

12 Banauch GI, Dhala A, Alleyne D, et al. Bronchial hyperreactivity and other inhalation lung injuries in rescue/recovery workers after the World Trade Center collapse. Crit Care Med 2005; 33: Suppl. 1, S102-S106.

13 Banauch GI, Hall C, Weiden M, et al. Pulmonary function after exposure to the World Trade Center collapse in the New York City Fire Department. Am J Respir Crit Care Med 2006; 174: 312-319.

14 Prezant DJ, Weiden M, Banauch GI, et al. Cough and bronchial responsiveness in firefighters at the World Trade Center site. N Engl J Med 2002; 347: 806-815.

15 Behrendt $\mathrm{H}$, Becker WM, Fritzsche $\mathrm{C}$, et al. Air pollution and allergy: experimental studies on modulation of allergen release from pollen by air pollutants. Int Arch Allergy Immunol 1997; 113: 69-74.
16 Knox RB, Suphioglu C, Taylor P, et al. Major grass pollen allergen Lol p 1 binds to diesel exhaust particles: implications for asthma and air pollution. Clin Exp Allergy 1997; 27: 246-251.

17 Ruffin J, Liu MY, Sessoms R, Banerjee S, Banerjee UC. Effects of certain atmospheric pollutants $\left(\mathrm{SO}_{2}, \mathrm{NO}_{2}\right.$ and $\mathrm{CO}$ ) on the soluble amino acids, molecular weight and antigenicity of some airborne pollen grains. Cytobios 1986; 46: 119-129.

18 Wyler C, Braun-Fahrlander C, Kunzli N, et al. Exposure to motor vehicle traffic and allergic sensitization. The Swiss Study on Air Pollution and Lung Diseases in Adults (SAPALDIA) Team. Epidemiology 2000; 11: 450-456.

19 Burgess JL, Nanson CJ, Bolstad-Johnson DM, et al. Adverse respiratory effects following overhaul in firefighters. Occup Environ Med 2001; 43: 467-473.

20 Schweizerische Feuerwehrkasse. [Swiss firebrigade association.] Swissfire. www.swissfire.ch Date last accessed: December 15, 2005.

21 Miedinger D, Stolz D, Gysin C, et al. Airway hyperresponsiveness and current asthma in Swiss professional firefighters and policemen. Proc Am Thorac Soc 2005; 2: A815.

22 Martin BW, Ackermann-Liebrich U, Leuenberger P, et al. SAPALDIA: methods and participation in the crosssectional part of the Swiss Study on Air Pollution and Lung Diseases in Adults. Soz Praventivmed 1997; 42: 67-84.

23 Burney PG, Luczynska C, Chinn S, Jarvis D. The European Community Respiratory Health Survey. Eur Respir J 1994; 7: 954-960.

24 Ackermann-Liebrich U, Leuenberger P, Schwartz J, et al. Lung function and long term exposure to air pollutants in Switzerland. Study on Air Pollution and Lung Diseases in Adults (SAPALDIA) Team. Am J Respir Crit Care Med 1997; 155: 122-129.

25 Leuenberger P, Kunzli N, Ackermann-Liebrich U, et al. [Swiss Study on Air Pollution and Lung Diseases in Adults (SAPALDIA).]. Schweiz Med Wochenschr 1998; 128: 150-161.

26 Sistek D, Tschopp JM, Schindler C, et al. Clinical diagnosis of current asthma: predictive value of respiratory symptoms in the SAPALDIA study. Swiss Study on Air Pollution and Lung Diseases in Adults. Eur Respir J 2001; 17: 214-219.

27 Tschopp JM, Sistek D, Schindler C, et al. Current allergic asthma and rhinitis: diagnostic efficiency of three commonly used atopic markers (IgE, skin prick tests, and Phadiatop). Results from 8329 randomized adults from the SAPALDIA Study. Swiss Study on Air Pollution and Lung Diseases in Adults. Allergy 1998; 53: 608-613.

28 Wuthrich B, Schindler C, Leuenberger P, AckermannLiebrich U. Prevalence of atopy and pollinosis in the adult population of Switzerland (SAPALDIA study). Swiss Study on Air Pollution and Lung Diseases in Adults. Int Arch Allergy Immunol 1995; 106: 149-156.

29 Wuthrich B, Schindler C, Medici TC, Zellweger JP, Leuenberger P. IgE levels, atopy markers and hay fever in relation to age, sex and smoking status in a normal adult Swiss population. SAPALDIA (Swiss Study on Air Pollution and Lung Diseases in Adults) Team. Int Arch Allergy Immunol 1996; 111: 396-402. 
30 Jayet PY, Schindler C, Kunzli N, et al. Reference values for methacholine reactivity (SAPALDIA study). Respir Res 2005; 6: 131.

31 Markowitz JS. Self-reported short- and long-term respiratory effects among PVC-exposed firefighters. Arch Environ Health 1989; 44: 30-33.

32 Froines JR, Hinds WC, Duffy RM, Lafuente EJ, Liu WC. Exposure of firefighters to diesel emissions in fire stations. Am Ind Hyg Assoc J 1987; 48: 202-207.

33 Punaxallio A, Lusa S, Luukkonen R. Protective equipment affects balance abilities differently in younger and older firefighters. Aviat Space Environ Med 2003; 74: 1151-1156.

34 Raven PB, Davis TO, Shafer CL, Linnebur AC. Maximal stress test performance while wearing a self-contained breathing apparatus. J Occup Med 1977; 19: 802-806.

35 Bolstad-Johnson DM, Burgess JL, Crutchfield CD, Storment S, Gerkin R, Wilson JR. Characterization of firefighter exposures during fire overhaul. AIHAJ 2000; 61: 636-641.

36 D'Amato G, Liccardi G, D'Amato M, Holgate S. Environmental risk factors and allergic bronchial asthma. Clin Exp Allergy 2005; 35: 1113-1124.

37 Jorres R, Nowak D, Magnussen H. The effect of ozone exposure on allergen responsiveness in subjects with asthma or rhinitis. Am J Respir Crit Care Med 1996; 153: $56-64$.

38 Molfino NA, Wright SC, Katz I, et al. Effect of low concentrations of ozone on inhaled allergen responses in asthmatic subjects. Lancet 1991; 338: 199-203.

39 D'Amato G, Spieksma FT, Liccardi G, et al. Pollen-related allergy in Europe. Allergy 1998; 53: 567-578.

40 D'Amato G. Urban air pollution and plant-derived respiratory allergy. Clin Exp Allergy 2000; 30: 628-636.

41 D'Amato G, Liccardi G, D'Amato M, Cazzola M. Outdoor air pollution, climatic changes and allergic bronchial asthma. Eur Respir J 2002; 20: 763-776.

42 Devalia JL, Rusznak C, Davies RJ. Allergen/irritant interaction-its role in sensitization and allergic disease. Allergy 1998; 53: 335-345.

43 Gauderman WJ, Avol E, Gilliland F, et al. The effect of air pollution on lung development from 10 to 18 years of age. N Engl J Med 2004; 351: 1057-1067.

44 Rusznak C, Devalia JL, Davies RJ. Airway response of asthmatic subjects to inhaled allergen after exposure to pollutants. Thorax 1996; 51: 1105-1108.

45 Emberlin J. Interaction between air pollutants and aeroallergens. Clin Exp Allergy 1995; 25: Suppl. 3, 33-39.

46 Diaz-Sanchez D, Tsien A, Fleming J, Saxon A. Combined diesel exhaust particulate and ragweed allergen challenge markedly enhances human in vivo nasal ragweed-specific $\mathrm{IgE}$ and skews cytokine production to a T helper cell 2-type pattern. J Immunol 1997; 158: 2406-2413.

47 Cacciola RR, Sarva M, Polosa R. Adverse respiratory effects and allergic susceptibility in relation to particulate air pollution: flirting with disaster. Allergy 2002; 57: 281-286.

48 Edwards J, Walters S, Griffiths RK. Hospital admissions for asthma in preschool children: relationship to major roads in Birmingham, United Kingdom. Arch Environ Health 1994; 49: 223-227.

49 Wjst M, Reitmeir P, Dold S, et al. Road traffic and adverse effects on respiratory health in children. BMJ 1993; 307: 596-600.

50 Omenaas E, Bakke P, Elsayed S, Hanoa R, Gulsvik A. Total and specific serum IgE levels in adults: relationship to sex, age and environmental factors. Clin Exp Allergy 1994; 24: 530-539.

51 Katelaris $\mathrm{CH}$, Carrozzi FM, Burke TV, Byth K. Patterns of allergic reactivity and disease in Olympic athletes. Clin J Sport Med 2006; 16: 401-405.

52 Adir Y, Shupak A, Laor A, Weiler-Ravell D. Large lungs in divers: natural selection or a training effect? Chest 2005; 128: 224-228.

53 O'Connor G, Sparrow D, Taylor D, Segal M, Weiss S. Analysis of dose-response curves to methacholine. An approach suitable for population studies. Am Rev Respir Dis 1987; 136: 1412-1417.

54 Schwartz J, Schindler C, Zemp E, et al. Predictors of methacholine responsiveness in a general population. Chest 2002; 122: 812-820.

55 Toelle BG, Peat JK, Salome CM, Mellis CM, Woolcock AJ. Toward a definition of asthma for epidemiology. Am Rev Respir Dis 1992; 146: 633-637.

56 Woolcock AJ. Asthma. In: Murray JF, Nadel JA, eds. Textbook of Respiratory Medicine. 2nd Edn. Philadelphia, W.B. Saunders Co. Ltd, 1994; pp. 1245-1258.

57 Woolcock AJ, Peat JK, Salome CM, et al. Prevalence of bronchial hyperresponsiveness and asthma in a rural adult population. Thorax 1987; 42: 361-368.

58 Chia KS, Jeyaratnam J, Chan TB, Lim TK. Airway responsiveness of firefighters after smoke exposure. $\mathrm{Br} J$ Ind Med 1990; 47: 524-527.

59 Nish WA, Schwietz LA. Underdiagnosis of asthma in young adults presenting for USAF basic training. Ann Allergy 1992; 69: 239-242.

60 Anderson SD, Schoeffel RE, Follet R, Perry CP, Daviskas E, Kendall M. Sensitivity to heat and water loss at rest and during exercise in asthmatic patients. Eur J Respir Dis 1982; 63: 459-471.

61 Leuppi JD, Brannan JD, Anderson SD. Bronchial provocation tests: the rationale for using inhaled mannitol as a test for airway hyperresponsiveness. Swiss Med Wkly 2002; 132: 151-158.

62 Caux C, O'Brien C, Viau C. Determination of firefighter exposure to polycyclic aromatic hydrocarbons and benzene during fire fighting using measurement of biological indicators. Appl Occup Environ Hyg 2002; 17: 379-386. 